Haya: The Saudi Journal of Life Sciences

Abbreviated Key Title: Haya Saudi J Life Sci

ISSN 2415-623X (Print) |ISSN 2415-6221 (Online)

Scholars Middle East Publishers, Dubai, United Arab Emirates

Journal homepage: https://saudijournals.com

Original Research Article

\title{
Acute Toxicity of Imidacloprid to Various Life Stages of the Giant Freshwater Prawn Macrobrachium rosenbergii, de Man, 1879
}

\author{
Kurishuparambil Varghese Stephy Rose ${ }^{1}$, Aneykutty Joseph ${ }^{2 *}$
}

\author{
${ }^{1}$ Department of Marine Biology, Microbiology and Biochemistry, School of Marine Sciences, Fine Arts Avenue, Cochin University of Science and \\ Technology, Cochin, 682016, Kerala, India \\ ${ }^{2}$ Department of Marine Biology, Microbiology and Biochemistry, School of Marine Sciences, Fine Arts Avenue, Cochin University of Science and \\ Technology, Cochin, 682016, Kerala, India
}

DOI: $10.36348 /$ sjls.2020.v05i12.006 $\quad$ | Received: 13.12 .2020 | Accepted: 21.12 .2020 | Published: 23.12 .2020

*Corresponding author: Aneykutty Joseph

Abstract

The present study was conducted invitro to evaluate the acute toxicity of a broad spectrum neonicotinoid, imidacloprid used by farmers contently to control piercing-sucking pests in the paddy fields of Kuttanad, a part of the Vembanad wetland ecosystem which is a Ramsar site of international importance in the state of Kerala, India, to various life stages of Macrobrachium rosenbergii, a commercially important indigenous prawn of Kuttanad. The median tolerance limit $\left(\mathrm{LC}_{50}\right)$ were calculated using the observations made on the mortality of prawns exposed to 5 different concentrations between the No Observable Effect Concentration (NOEC) and Lowest Observable Effect Concentration (LOEC) of biocides for a period of $96 \mathrm{~h}$. $\mathrm{LC}_{50}$ values for $24,48,72$ and $96 \mathrm{~h}$ of imidacloprid was determined by probit analysis using SPSS version 16.0. The study revealed that the $96 \mathrm{~h} \mathrm{LC}_{50}$ concentrations for imidacloprid as $0.009,5.0234$ and 42.611 $\mathrm{mg} / \mathrm{l}$ in post-larvae $(0.041 \pm 0.02 \mathrm{~g})$, juvenile $(3.5 \pm 1.5 \mathrm{~g})$ and adult $(17.5 \pm 2.5 \mathrm{~g})$, respectively of M. rosenbergii. Based on the $\mathrm{LC}_{50}$ values, safe concentrations found out for imidacloprid using Hart's formula were 0.002, 1.000 and 15.138 $\mathrm{mg} / \mathrm{l}$, in post-larvae, juvenile and adult $M$. rosenbergii, respectively. The field application concentration of imidacloprid is $0.003 \mathrm{mg} / \mathrm{l}$ which is 3 times higher than the safe concentration of imidacloprid in post-larvae, whereas it is lower than the safe concentration in juvenile and adult $M$. rosenbergii. The results revealed that the application of imidacloprid in the paddy fields of Kuttanad has a lethal effect on post-larvae of $M$. rosenbergii causing a threat to the existence of species in its homeland.

Keywords: Imidacloprid, acute toxicity, Macrobrachium rosenbergii, postlarvae, juvenile, adult.

Copyright () 2020 The Author(s): This is an open-access article distributed under the terms of the Creative Commons Attribution 4.0 International License (CC BY-NC 4.0) which permits unrestricted use, distribution, and reproduction in any medium for non-commercial use provided the original author and source are credited.

\section{INTRODUCTION}

Macrobrachium rosenbergii, the giant freshwater prawn of the Palaemonidae family is a prime species for aquaculture because of its large size, rapid growth and high nutritive value[1]. It is a true denizen of Kuttanad, a part of the Vembanad wetland ecosystem, which is one of the internationally recognized Ramsar sites (location no. 1214) in Kerala, southwest coast of India. The region extends from $9^{\circ}$ $17^{\prime}$ to $9^{\circ} 40^{\prime} \mathrm{N}$ latitude and $76^{\circ} 19^{\prime}$ to $76^{\circ} 33^{\prime} \mathrm{E}$ longitude, comprising an area of $1100 \mathrm{sq}$. km. It is one of the most fertile lands of the world, having 55,000 ha of paddy fields, vast stretches of backwaters and bordering mangrove formations[2]. A very abundant fishery of $M$. rosenbergii is reported in Vembanad Lake system, its confluent rivers and proximate inundated paddy fields [3]. The postlarvae and juveniles of $M$. rosenbergii have been reported to feed upon rice grains and small worms in the polders adjacent to Vembanad Lake[4, 5]. Its supreme role in international merchandise, earning overseas revenue for India, uplifted its concernment in the inland waters of the nation[3].

However, paddy cultivation has been facing severe agrarian distress for the last five decades owing to a variety of factors[6]. Pesticides act as a vital tool in promoting food productivity necessary to meet the increasing human demand. About 485 tonnes of pesticides are being applied in the paddy fields of Kuttanad every year[7]. Only $0.1 \%$ of the pesticides applied to control the target pests pacify the purpose and the remaining is left to impact the surrounding biota and environment [8]. Imidacloprid (1- (6-chloro-3pyridylmethyl) - N-nitroimidazolidin-2-ylideneamine) is a nitroguanidine insecticide that belongs to the neonicotinoid family[9] commonly used in the paddy 
fields of Kuttanad, as a possible alternative for commonly used organophosphorus pesticides. It is a versatile, broad-spectrum insecticide which acts as a contact and stomach poison against sucking insects[1012] including strains resistant to conventional pesticides. The application of imidacloprid is done as foliar sprays at the first sign of aphid infestation, with a maximum of two applications per season, as its insecticidal activity lasts for about 3 months [13]. As its application is relatively for a short period when compared to other insecticides, it is used in the largest volume world wide $[14,15]$. Due to its relatively high solubility (0.61 g/l) [16], imidacloprid moves easily from paddy fields to irrigation channels of the field [17] via input from spray drift, leaching, or runoff and eventually reaches the nearby aquatic ecosystem[18] inhabited by the postlarvae and juveniles of $M$. rosenbergii [4], where it is reported to be persistant [19]. The molecule exhibits a novel mode of action as it is an agonist of the nicotinic acetylcholine receptor (nAChR) interfering with neural control and coordination of various physiological activities [20]. Imidacloprid causes muscle cramps, weakness and twitching resulting in impairment of invertebrate movements [21], which inturn can lead to starvation and death via dysfunctional feeding behavior [22] due to paralysis[23]. Within this context, non-target aquatic organisms potentially could be exposed to imidacloprid via water, sediments [24] and food sources [25]. Dissipation time $50 \%$ for the water phase (DT50 water) values ranged 30 to $150 \mathrm{~d}$ and a DT50 water value of $90 \mathrm{~d}$ could possibly lead to long-term exposure of aquatic ecosystems [26]. Significant effects have been recognized in different trophic levels of the aquatic niche after biomagnification [27].

Toxicity of several pesticides have been studied in Machrobrachium sp., viz. Macrobrachium amazonicum [28], Macrobrachium borellii [29], Macrobrachium lamarrei [30-32], Macrobrachium malcolmsonii [33-35], Macrobrachium naso and Macrobrachium dayanum [36], Macrobrachium nipponense [37-39], Macrobrachium olfersii [40] and $M$. rosenbergii [41-46]. The toxicity of imidacloprid has been studied in several crustaceans [47-51]. However, no serious attempt has been made on the toxic sequelae attributed to imidacloprid in $M$. rosenbergii. The present study was conducted to elucidate the susceptibility of the giant freshwater prawn $M$. rosenbergii at different life-history stages, viz. postlarvae, juvenile and adult to imidacloprid, and thereby determine the median lethal concentration $\left(\mathrm{LC}_{50}\right)$ and safe concentration of imidacloprid to postlarvae, juvenile and adult stages of $M$. rosenbergii.

\section{MATERIALS AND METHODS Animal rearing}

The toxicity assessment was carried out on different life stages of $M$. rosenbergii such as postlarvae, juvenile and adult, procured from Sea View
Prawn Hatchery, Thriprayar, Kerala, India. They were brought to the aquatic animal rearing facility of the Department of Marine Biology, Microbiology and Biochemistry located at the School of Marine Sciences, Cochin University of Science and Technology, Kerala, India, wherein the study has been conducted. Prior to the experiment, prawns were held in experimental glass tanks for a period of 15 days and fed with commercial pellet feed to get acclimatized to the ambient condition. Prawns were acclimatized and starved for $24 \mathrm{~h}$ prior to the experimentation.

\section{Analysis of water quality}

The water quality parameters such as temperature (Amber mercury thermometer, Amber hydrometers, Ahmedabad, India.), pH (Cyberscan pH 510 Meter, Aarkey Labtronix India.) and dissolved oxygen (Winkler's method) were evaluated every day. Alkalinity, total ammonia and hardness were determined at the beginning and the end of the experiment [52]. Water quality variables were determined independently for each treatment to establish whether the prawns were maintained at appropriate favorable conditions [53].

\section{Experimental setup}

Assessment of the median lethal concentration $\left(\mathrm{LC}_{50}-96 \mathrm{~h}\right)$ of imidcloprid to various lifestages of $M$. rosenbergii were done based on the manual of the Environmental Protection Agency USA [54]. Experiments were carried out using 540 prawns (180 postlarvae/18 experimental units, 180 juveniles / 18 experimental units and 180 adults / 18 experimental units). The units consisted of 601 glass tanks with 10 postlarvae $(0.041 \pm 0.02 \mathrm{~g} ; 1.45 \pm 0.25 \mathrm{~cm})$ in $201 \mathrm{of}$ test solution, 10 juveniles $(3.5 \pm 1.5 \mathrm{~g} ; 7.26 \pm 0.51 \mathrm{~cm})$ in 301 of test solution and 10 adult $(17.5 \pm 2.5 \mathrm{~g}$; $12.63 \pm 0.42 \mathrm{~cm})$ in 401 of test solution. Experimental units were equipped with aeration systems and a natural photoperiod of $12 \mathrm{~h} / 12 \mathrm{~h}$ (light / dark).

\section{Range finding test}

A preliminary range-finding test was conducted for a period of $96 \mathrm{~h}$ with a wide range of concentrations viz., $0.001,0.01,0.1,1.0,10$ and 100 ppm of imidcloprid. The concentrations between the No Observable Effect Concentration (NOEC) and Lowest Observable Effect Concentration (LOEC) of imidacloprid were determined by observing the mortality after $96 \mathrm{~h}$ and used for the acute toxicity experiments.

\section{Acute toxicity test}

Acute toxicity tests were carried out with six different concentrations viz., 0, 0.002, 0.004, 0.006, 0.008 and $0.010 \mathrm{ppm} ; 0,2,4,6,8$ and $10 \mathrm{ppm}$; and 0 , 20, 40, 60, 80 and $100 \mathrm{ppm}$ Commercial-grade imidacloprid (Bayer CropScience Pty Ltd - Confidor having active ingredient of $17.8 \% \mathrm{SL}$ ), respectively for postlarvae, juvenile and adult $M$. rosenbergii each in 
triplicates. Test solutions were renewed every $24 \mathrm{~h}$ to maintain even concentration of toxicants, to remove organic wastes and to avoid oxygen depletion.

The criterion used to affirm the lethality was the total absence of any kind of movement or reaction to mechanical stimuli using a glass rod. Prawns were observed every $1 \mathrm{~h}$ for the first $8 \mathrm{~h}$ and every $12 \mathrm{~h}$ between $8 \mathrm{~h}$ and $96 \mathrm{~h}$ [55].

\section{Determination of $\mathrm{LC}_{\mathbf{5 0}}$ concentration}

Mortality of postlarvae, juvenile and adult stages of $M$. rosenbergii exposed to each concentration viz., 0, 0.002, 0.004, 0.006, 0.008 and $0.010 \mathrm{ppm} ; 0,2$,
4, 6, 8 and $10 \mathrm{ppm}$; and 0, 20, 40, 60, 80 and $100 \mathrm{ppm}$ of imidacloprid after 24, 48, 72 and $96 \mathrm{~h}$ were recorded and used for estimation of the $\mathrm{LC}_{50}$ values by the probit method, using SPSS version 16.0[56].

\section{Determination of Safe concentration}

Safe concentration is the concentration of pollutants that supposedly has no adverse effect on the organism [57]. From the 24 and $48 \mathrm{~h} \mathrm{LC}_{50}$ values of imidacloprid to postlarvae, juvenile and adult $M$. rosenbergii determined by probit analysis, safe concentration of imidacloprid to postlarvae, juvenile and adult $M$. rosenbergii was calculated by the method described by Hart et al.(1945).
Safe concentration $=\frac{48 \mathrm{~h} \mathrm{LC} 50 \times 0.2}{\mathrm{~S}^{2}}$

\section{STATISTICAL ANALYSIS}

The median lethal concentration of imidacloprid was calculated by the probit method [56]. Briefly, using different concentrations viz., 0, 0.002, 0.004, 0.006, 0.008 and 0.010 ppm; 0, 2, 4, 6, 8 and 10 ppm; and 0, 20, 40, 60, 80 and 100 ppm of imidacloprid and corresponding mortality data collected after 24,48 , 72 and $96 \mathrm{~h}$ of exposure, linear regression were carried out in SPSS version 16.0 to generate a probit (short form of probability unit) list. The $\mathrm{LC}_{50}$ values of imidacloprid to postlarvae, juvenile and adult $M$. rosenbergii after 24, 48, 72 and $96 \mathrm{~h}$ with $95 \%$ confidence intervals were determined by looking up the concentration corresponding with probit of 5.00 (probit for $50 \%$ mortality / $\mathrm{LC}_{50}$ ) [56].

\section{Where $\mathrm{S}=24 \mathrm{~h} \mathrm{LC}_{50}$ $48 \mathrm{~h} \mathrm{LC}_{50}$}

Table-1: Water quality parameters of acute toxicity tests of imidacloprid in different life-history stages (postlarvae, juvenile and adult) of $M$. rosenbergii

\begin{tabular}{|c|c|c|c|c|c|c|c|}
\hline \multirow{2}{*}{$\begin{array}{c}\text { Life-history } \\
\text { stages }\end{array}$} & \multirow[t]{2}{*}{ Variables } & \multicolumn{6}{|c|}{ Concentrations (mg/l) } \\
\hline & & 0.000 & 0.002 & 0.004 & 0.006 & 0.008 & 0.010 \\
\hline \multirow{6}{*}{ 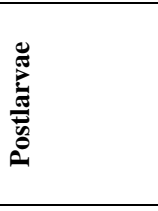 } & Temperature $\left({ }^{\circ} \mathrm{C}\right)$ & $27.5 \pm 0.5$ & $27.5 \pm 0.5$ & $27.5 \pm 0.5$ & $27.5 \pm 0.5$ & $27.5 \pm 0.5$ & $27.5 \pm 0.5$ \\
\hline & $\mathrm{pH}$ & $7.4 \pm 0.1$ & $7.4 \pm 0.1$ & $7.4 \pm 0.1$ & $7.5 \pm 0.1$ & $7.5 \pm 0.1$ & $7.5 \pm 0.1$ \\
\hline & Dissolved oxygen $\left(\mathrm{mg} \cdot \mathrm{l}^{-1}\right)$ & $6.8 \pm 0.4$ & $6.6 \pm 0.8$ & $6.7 \pm 0.7$ & $6.7 \pm 0.9$ & $6.8 \pm 0.8$ & $6.8 \pm 0.6$ \\
\hline & Hardness $\left(\mathrm{mg} \cdot 1^{-1} \mathrm{CaCO}_{3}\right)$ & $28.6 \pm 0.8$ & $28.4 \pm 1.1$ & $29.2 \pm 1.4$ & $29.6 \pm 1.2$ & $29.4 \pm 1.1$ & $30.2 \pm 0.6$ \\
\hline & Alkalinity $\left(\mathrm{mg} \cdot \mathrm{l}^{-1}\right)$ & $22.7 \pm 0.1$ & $22.3 \pm 0.2$ & $21.7 \pm 0.2$ & $21.4 \pm 0.3$ & $21.1 \pm 0.6$ & $20.8 \pm 0.4$ \\
\hline & Total ammonia $\left(\mathrm{mg} \cdot \mathrm{l}^{-1}\right)$ & $0.206 \pm 0.3$ & $0.41 \pm 0.2$ & $0.49 \pm 0.44$ & $0.47 \pm 0.42$ & $0.48 \pm 0.36$ & $0.46 \pm 0.72$ \\
\hline & & 0.00 & 2.00 & 4.00 & 6.00 & 8.00 & 10.00 \\
\hline \multirow{7}{*}{ } & Temperature $\left({ }^{\circ} \mathrm{C}\right)$ & $27.4 \pm 0.5$ & $27.3 \pm 0.5$ & $27.5 \pm 0.2$ & $27.2 \pm 0.5$ & $27.6 \pm 0.4$ & $27.1 \pm 0.5$ \\
\hline & $\mathrm{pH}$ & $7.5 \pm 0.1$ & $7.4 \pm 0.1$ & $7.4 \pm 0.1$ & $7.4 \pm 0.1$ & $7.5 \pm 0.1$ & $7.6 \pm 0.1$ \\
\hline & Dissolved oxygen $\left(\mathrm{mg} \cdot \mathrm{l}^{-1}\right)$ & $6.6 \pm 0.4$ & $6.2 \pm 0.8$ & $6.7 \pm 0.3$ & $6.2 \pm 0.7$ & $6.8 \pm 0.1$ & $6.8 \pm 0.2$ \\
\hline & Hardness $\left(\mathrm{mg} \cdot \mathrm{l}^{-1} \mathrm{CaCO}_{3}\right)$ & $28.2 \pm 0.8$ & $28.4 \pm 1.2$ & $29.3 \pm 1.2$ & $29.6 \pm 1.4$ & $29.4 \pm 1.3$ & $30.1 \pm 0.4$ \\
\hline & Alkalinity $\left(\mathrm{mg} \cdot 1^{-1}\right)$ & $22.6 \pm 0.1$ & $22.4 \pm 0.3$ & $21.8 \pm 0.2$ & $21.6 \pm 0.2$ & $21.1 \pm 0.8$ & $20.7 \pm 0.5$ \\
\hline & Total ammonia $\left(\mathrm{mg} \cdot \mathrm{l}^{-1}\right)$ & $0.208 \pm 0.2$ & $0.43 \pm 0.3$ & $0.48 \pm 0.47$ & $0.47 \pm 0.32$ & $0.48 \pm 0.23$ & $0.46 \pm 0.92$ \\
\hline & & 0.00 & 20.00 & 40.00 & 60.00 & 80.00 & 100.00 \\
\hline \multirow{6}{*}{ 흘 } & Temperature $\left({ }^{\circ} \mathrm{C}\right)$ & $27.3 \pm 0.6$ & $27.4 \pm 0.5$ & $27.5 \pm 0.5$ & $27.8 \pm 0.2$ & $27.5 \pm 0.3$ & $27.6 \pm 0.4$ \\
\hline & $\mathrm{pH}$ & $7.4 \pm 0.1$ & $7.3 \pm 0.1$ & $7.4 \pm 0.1$ & $7.4 \pm 0.1$ & $7.5 \pm 0.1$ & $7.5 \pm 0.1$ \\
\hline & Dissolved oxygen $\left(\mathrm{mg} \cdot \mathrm{l}^{-1}\right)$ & $6.4 \pm 0.4$ & $6.6 \pm 0.4$ & $6.3 \pm 0.7$ & $6.7 \pm 0.3$ & $6.2 \pm 0.8$ & $6.4 \pm 0.6$ \\
\hline & Hardness $\left(\mathrm{mg} \cdot \mathrm{l}^{-1} \mathrm{CaCO}_{3}\right)$ & $28.5 \pm 0.8$ & $28.6 \pm 1.2$ & $29.1 \pm 0.8$ & $29.7 \pm 1.5$ & $29.9 \pm 0.1$ & $30.2 \pm 0.6$ \\
\hline & Alkalinity $\left(\mathrm{mg} \cdot \mathrm{l}^{-1}\right)$ & $23.1 \pm 0.1$ & $22.6 \pm 0.2$ & $21.8 \pm 0.2$ & $21.4 \pm 0.8$ & $21.1 \pm 0.2$ & $20.9 \pm 0.3$ \\
\hline & Total ammonia $\left(\mathrm{mg} \cdot \mathrm{l}^{-1}\right)$ & $0.207 \pm 0.3$ & $0.38 \pm 0.2$ & $0.47 \pm 0.34$ & $0.47 \pm 0.72$ & $0.48 \pm 0.16$ & $0.47 \pm 0.82$ \\
\hline
\end{tabular}




\section{Acute toxicity of imidacloprid to $M$. rosenbergii}

The 24, 48, 72 and $96 \mathrm{~h} \mathrm{LC}_{50}$ concentrations of imidacloprid in different life-history stages of $M$. rosenbergii is shown in Table 2 . With an increase in time period, there was a decline in the $\mathrm{LC}_{50}$ value viz., 0.046 to $0.009,7.362$ to 5.031 and 88.104 to 42.611 $\mathrm{mg} / \mathrm{l}$, respectively for post larvae, juvenile and adult $M$. rosenbergii. The $96 \mathrm{~h} \quad \mathrm{LC}_{50}$ values indicate that postlarvae are the most vulnerable to imidacloprid toxicity being having the lowest concentration for lethality when compared to later life stages. Whereas, adults are the most resistant to imidacloprid toxicity being having the highest concentration for lethality when compared to early life stages. In all life stages examined, the mortality of prawns exposed to imidacloprid surged with that of exposure period and concentration. Mortality observed for control $M$. rosenbergii (not exposed to imidacloprid) during the trial period was negligible and may be related to the agonistic behavior of conspecifics attacking/eating the other leading to injury or death known as cannibalism.

Table-2: Acute toxicity $\left(\mathrm{LC}_{50}\right.$ values $\left.(\mathrm{mg} / \mathrm{l})\right)$ of imidacloprid in different life-history stages (postlarvae, juvenile and adult) of $M$. rosenbergii.

\begin{tabular}{|c|c|c|c|}
\hline \multirow{2}{*}{ Exposure period (h) } & LC $_{\mathbf{5 0}}$ values (mg/l) in different life-history stages of M. rosenbergii. \\
\cline { 2 - 4 } & Postlarvae & Juvenile & Adult \\
\hline 24 & 0.046 & 7.362 & 88.104 \\
\hline 48 & 0.025 & 6.471 & 83.752 \\
\hline 72 & 0.015 & 5.445 & 63.679 \\
\hline 96 & 0.009 & 5.023 & 42.611 \\
\hline
\end{tabular}

Acute toxicity of imidacloprid in postlarvae of $M$. rosenbergii

Percentage mortality of post-larvae of $M$. rosenbergii exposed to different concentrations of Imidacloprid for 24, 48, 72, and $96 \mathrm{~h}$ are given in Fig. 1. Postlarvae of $M$. rosenbergii exposed to $0.002 \mathrm{mg} / \mathrm{l}$ imidacloprid showed no mortality throughout the experimental period. Whereas $10 \%$ and $40 \%$ mortality were observed, respectively at $0.004 \mathrm{mg} / \mathrm{l}$ and 0.008 $\mathrm{mg} / \mathrm{l}$ of imidacloprid after $96 \mathrm{~h}$. At a higher concentration, $0.010 \mathrm{mg} / \mathrm{l}$ of imidacloprid, mean mortality was $60 \%$ after $96 \mathrm{~h}$. However, when comparing the relationship between mortality and imidacloprid concentration by the probit method and regression analysis, the lethal concentration for $50 \%$ of the prawns after $96 \mathrm{~h}$ was determined as $0.009 \mathrm{mg} / \mathrm{l}$ with $95 \%$ confidence intervals $0.005-0.017 \mathrm{mg} / \mathrm{l}$. Thus, a safe level of exposure for the postlarvae of $M$. rosenbergii was calculated to be $0.002 \mathrm{mg} / \mathrm{l}$.

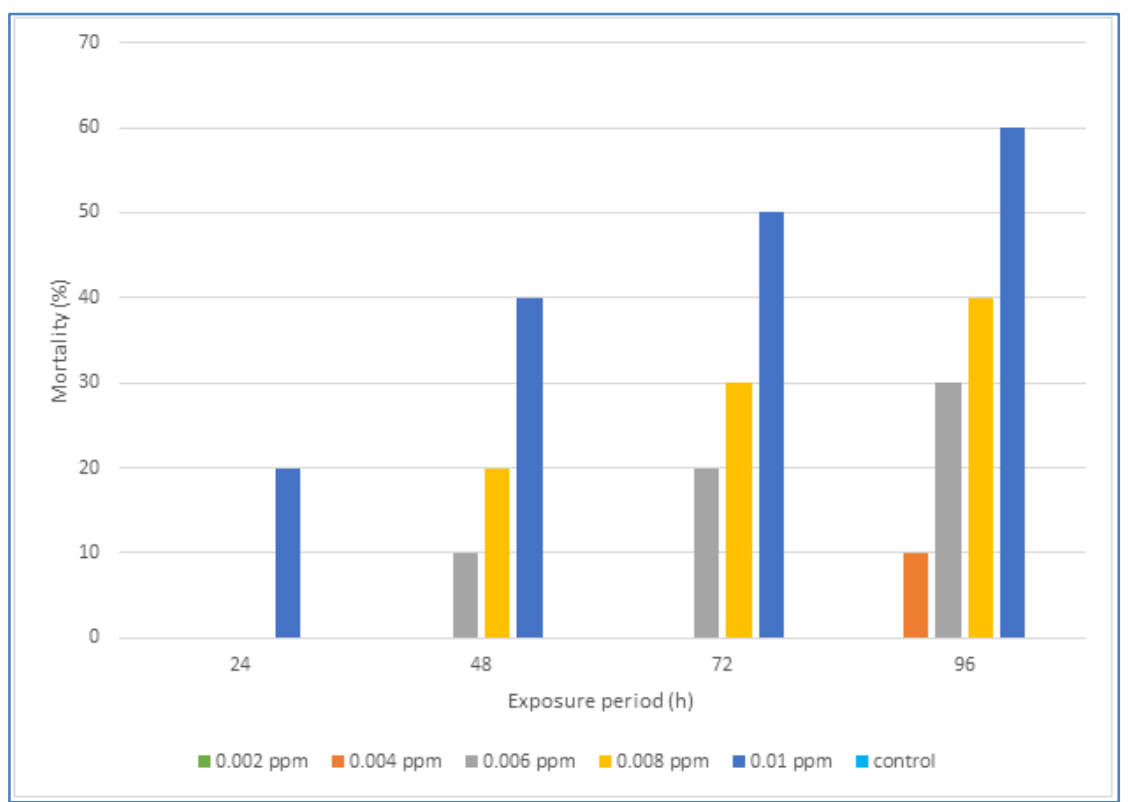

Fig-1: Mean cumulative mortality (\%) of post-larvae of $M$. rosenbergii exposed to different concentrations of imidacloprid for $24,48,72$, and $96 \mathrm{~h}$.

Acute toxicity of imidacloprid in juvenile $M$. rosenbergii

Mean cumulative mortality (\%) of juvenile $M$. rosenbergii exposed to different concentrations of imidacloprid for 24, 48, 72, and $96 \mathrm{~h}$ are given in Fig. 2.
Juveniles of $M$. rosenbergii exposed to $2 \mathrm{mg} / \mathrm{l}$ imidacloprid showed no mortality up to $48 \mathrm{~h}$ but showed $10 \%$ and $20 \%$ mortality, respectively after 72 and 96 h. After 96 h, juveniles exposed to imidacloprid showed $40 \%$ mean mortality at concentration $4 \mathrm{mg} / \mathrm{l}$ 
and $60 \%$ mortality at concentration $6 \mathrm{mg} / \mathrm{l} .100 \%$ of mortality was observed at $10 \mathrm{mg} / \mathrm{l}$ after $24 \mathrm{~h}$. The median lethal concentration by the probit method and regression analysis, after $96 \mathrm{~h}$ was determined as 5.031 $\mathrm{mg} / \mathrm{l}$ with $95 \%$ confidence intervals $3.488-6.945 \mathrm{mg} / \mathrm{l}$. Thus, a safe level of exposure for the juveniles of $M$. rosenbergii was calculated as $1.000 \mathrm{mg} / \mathrm{l}$.

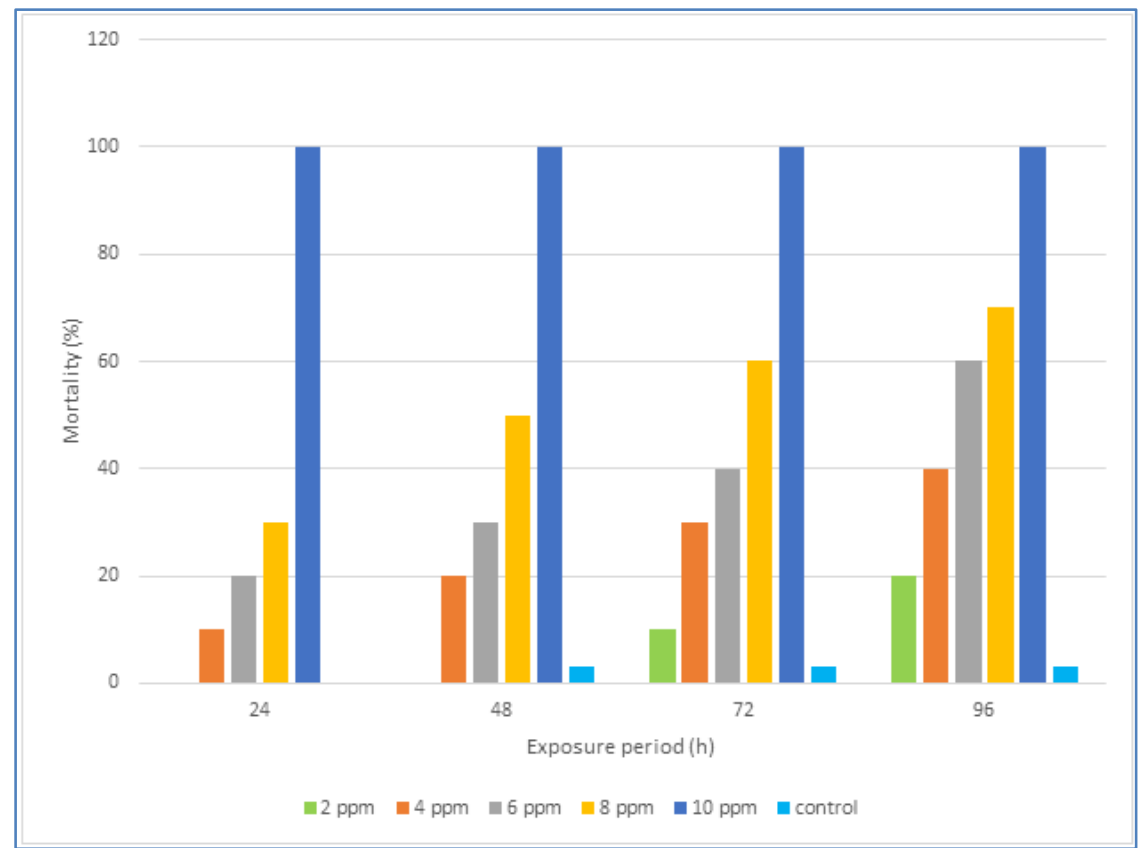

Fig-2: Mean cumulative mortality (\%) of juvenile $M$. rosenbergii exposed to different concentrations of imidacloprid for 24, 48, 72 , and $96 \mathrm{~h}$.

Acute toxicity of imidacloprid in adult $M$. rosenbergii

Mean cumulative mortality $(\%)$ of adult $M$. rosenbergii exposed to different concentrations of imidacloprid for 24, 48, 72, and $96 \mathrm{~h}$ are given in Fig. 3. Adult M. rosenbergii exposed to 20, 40 and $60 \mathrm{mg} / \mathrm{l}$ imidacloprid showed $20 \%, 45 \%$ and $60 \%$ mortality, respectively after $96 \mathrm{~h}$. However, $80 \%$ and $100 \%$ mortality were observed, respectively at $80 \mathrm{mg} / \mathrm{l}$ and $100 \mathrm{mg} / \mathrm{l}$ of imidacloprid after $96 \mathrm{~h}$. The concentration for $50 \%$ mortality of the prawns after $96 \mathrm{~h}$ was determined as $42.6579 \mathrm{mg} / \mathrm{l}$ with $95 \%$ confidence intervals $29.643-55.402 \mathrm{mg} / \mathrm{l}$ by probit analysis. Thus, a safe level of exposure for the adults of $M$. rosenbergii is $15.138 \mathrm{mg} / \mathrm{l}$.

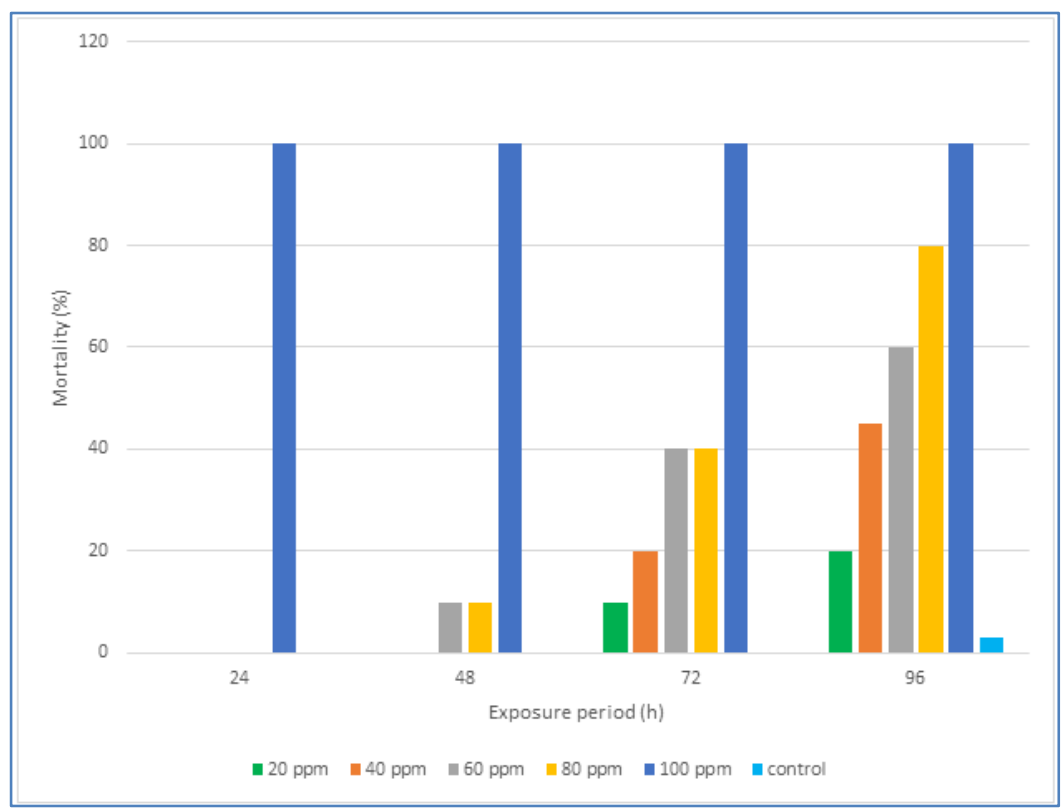

Fig-3: Mean cumulative mortality (\%) of adult $M$. rosenbergii exposed to different concentrations of imidacloprid for 24,48 , 72 , and $96 \mathrm{~h}$ 


\section{DISCUSSION}

\section{Water quality parameters}

Water quality parameters were maintained within the optimal range reported for $M$. rosenbergii [58]. As none of the water quality parameters measured in this study was stressful for the prawns, the lethal effects observed could be due to the toxicity of imidacloprid.

\section{Acute toxicity of imidacloprid to $M$. rosenbergii}

Acute toxicity assessment of imidacloprid to various life stages of the giant freshwater prawn, $M$. rosenbergii revealed that the postlarvae of $M$. rosenbergii are susceptible to imidacloprid, which is said to be used to control aphids, whiteflies and leafhoppers affecting paddy, cotton, chilly, okra and ground nut [59]. Hence the widespread use of imidacloprid in the paddy fields of Kuttanad poses a critical threat to postlarvae of $M$. rosenbergii, a prime candidate for the freshwater aquaculture in Kuttanad. Acute toxicity is an important parameter for toxicity test, which throw light on whether the changes resulting from exposure is detrimental to aquatic organisms [57]. The consequent estimation of median lethal concentration $\left(\mathrm{LC}_{50}\right)$ is a standard practice in aquatic toxicology studies $[60,61]$.

Comparing toxicity of imidacloprid in the different life stages of $M$. rosenbergii, it was found that the sensitivity to imidacloprid is related to the developmental stage of the organism. In the present study, it has been found that the postlarvae of $M$. rosenbergii are more sensitive to imidacloprid than juvenile and adult, as the field application concentration $(0.003 \mathrm{mg} / \mathrm{l})$ is higher than the safe concentration determined for postlarvae $(0.002 \mathrm{mg} / \mathrm{l})$, but lower than those of juvenile $(1.000 \mathrm{mg} / \mathrm{l})$ and adult $(15.138 \mathrm{mg} / \mathrm{l})$. The safe concentration found out for postlarvae of $M$. rosenbergii in this study corroborate the idea of EFSA, 2008, which suggested the maximum permissible concentration between 0.0002 and $0.019 \mathrm{mg} / \mathrm{l}$. The $96 \mathrm{~h}$ $\mathrm{LC}_{50}$ of imidacloprid for the postlarvae has been calculated as $0.009 \mathrm{mg} / \mathrm{l}$. This is in agreement with the previous research that the postlarvae are more sensitive than later life stages of $M$. rosenbergii $[62,63]$ or other Macrobrachium species $[64,65]$ as later stages developed resistance. The susceptability of an organism to a toxicant can differ depending on its size, age and developmental stage [66], because several enzymes may have differential activities along with development or aging [67]. Lipophilic nature of imidacloprid helps them to easily diffuse into cells [68], thereby causing alterations in the physico-chemical properties and $\mathrm{pH}$ of the cytoplasm, destruction of the membranes of the organelles, disruption of the normal functioning of the cell proteins [69] and alteration in activity of enzymes viz. acetylcholinesterase, acid phosphatase, alkaline phosphatase, cytochrome oxidase, glutamic oxalic transaminase, glutamic pyruvic transaminase, lactic dehydrogenase, protease and succinic dehydrogenase
[70]. Imidacloprid is found to reduce the food availability and quality for postlarvae of $M$. rosenbergii by accumulatng in green algae: Desmodesmus subspicatus [71], Desmodesmus sp [72], diatoms: Gomphonema gracile, Planothidium lanceolatum [72]; chironomids: Chironomus riparius [73, 74], Chironomus tentans [11], Chironomus dilutes [75]; amphipods: Hyalella Azteca [11, 76, 77], Gammarus fossarum [72], Gammarus pulex [78], Gammarus roeseli [79] and other small crustaceans: Daphnia magna [80-82], Ceriodaphnia dubia [76]. Thus the bioaccumulative nature of imidacloprid in food webs may be exacerbated and lead to biomagnification between the lower and upper trophic levels [83]. Even at sublethal levels, toxicants are found to severely impair the reproductive capacity of Macrobrachium sp. by disrupting germinal epithelium and thereby spermatogenesis and oogenesis [36].

In the early stages of development, the organisms are generally more sensitive due to increased mitotic activity [84], and also possibly their higher ratios of surface area to volume, being small sized. This variation in susceptability of various ontogenetic stages has been observed in Macrobrachium spp., exposed to other pesticides[85], heavy metals [86] and nitrogen compounds such as ammonia [87] and nitrite [88]. Imidacloprid is found to induce endocrine turmoil [89], impairement of mitochondria [90], oxidative desecration [91], and immunological disorders [92] in various invertebrates. Once the accumulation of the insecticide in hepatopancreas exceeds its capacity to metabolize it, the ill effects of insecticide begin to set in. Inhibition of $\mathrm{AChE}$ is reported to be accompanied by an increase in acetylcholine ( $\mathrm{ACh}$ ) levels that can be dangerous since paralysis, as it leads to starvation due to feeding incapability, swimming disability, difficulties in identification and spatial orientation of the organism [93] and almost surely, will not be able to reproduce [94]. Indeed, insensitiveness of the organism makes them defenceless to predator attacks in the rice-agro ecosystems.

Postlarvae of $M$. rosenbergii are highly sensitive to imidacloprid when compared with results reported on juvenile Labeo rohita [95] and common carp larvae [96]. The reason behind the higher toxicity of imidacloprid to invertebrates than those of vertebrates is due to the mode of action of imidacloprid. Imidacloprid functions by disrupting the nicotinic acetylcholine receptors ( $\mathrm{nAChR}$ ) in the central nervous system of insects. The vertebrates' nAChRs differ from those in insects', and hence exert less toxicity in vertebrates than invertebrates. In this regard, it must be pointed out that, given the short life cycles of $M$. rosenbergii, the affected populations will certainly diminish in a very short time [29]. 


\section{CONCLUSION}

Acute toxicity assessment of imidacloprid to various life stages of the giant freshwater prawn, $M$. rosenbergii highlights that the postlarvae of $M$. rosenbergii have the lowest value of $96 \mathrm{~h} \mathrm{LC}_{50}(0.009$ $\mathrm{mg} / \mathrm{l}$ ) when compared to that of juveniles and adults. Indeed, field application concentration $(0.003 \mathrm{mg} / \mathrm{l})$ of imidacloprid is higher than the safe concentration $(0.002 \mathrm{mg} / \mathrm{l})$ estimated for postlarvae. Thus postlarvae of $M$. rosenbergii are susceptible to imidacloprid in its habitat. Although, juveniles and adults are not susceptible to imidacloprid in its ecosystem, being having a safe concentration $(1.000 \mathrm{mg} / \mathrm{l}$ and 15.138 $\mathrm{mg} / \mathrm{l}$ for juveniles and adults, respectively) higher than the field application concentration, the lethal effect of imidacloprid to postlarvae of $M$. rosenbergii poses a threat to the existence of the species in its homeland. Hence, the present study reveals that imidacloprid should be maintained below safe concentration in the agricultural area to suppress the potential hazard caused by imidacloprid to the species in the natural ecosystem. Immediate attention of regulators, who currently assess the environmental impact of this toxicant is warrented. Further studies on the sublethal effects of imidacloprid on $M$. rosenbergii need to be performed to elucidate toxicity pathways that result in the death of the organism.

\section{ACKNOWLEDGMENT}

The authors are thankful to the Department of Marine Biology, Microbiology and Biochemistry, School of Marine Sciences, Cochin University of Science and Technology for providing the necessary research facilities. The first author is thankful to University Grant Commission - Maulana Azad National Fellowship (UGC-MANF) for financial support.

\section{REFERENCE}

1. Kurian, C. V., \& Sebastian, V. O. (1976). Prawns and prawn fisheries of India. Prawns and prawn fisheries of India.

2. Kokkal, K., Harinarayanan, P., \& Aswathy, M. V. (2011). Possible impacts of climate change on water resources of the humid tropics (Kerala). Climate Change Adaptation Strategies in Agriculture and Allied Sectors, 126.

3. Kurup, B.M., \& Harikrishnan, M. (1992) Reviving the Macrobrachium rosenbergii (de Man) fishery in Vembanad lake, India.

4. John, M. C. (1957). Bionomics and life history of Macrobrachium rosenbergii (de Man). Bull. Cent. Res. Inst. Univ. Travencore, Tiruvandrum Ser. C, 5, 93-102.

5. Raman, K. (1967). Observations on the fishery and biology of the giant fresh water prawn Macrobrachium rosenbergii de Man.

6. Swaminathan, M. S. (Ed.). (2007). Agriculture cannot wait: new horizons in Indian agriculture. Academic Foundation.
7. KWBSP. Kuttanad Water Balance Study Final Report. (1990). Vol. 2, Annexes A-E.

8. Pimentel, D. (1995). Amounts of pesticides reaching target pests: environmental impacts and ethics. Journal of Agricultural and environmental Ethics, 8(1), 17-29.

9. Jeschke, P., Nauen, R., Schindler, M., \& Elbert, A. (2011). Overview of the status and global strategy for neonicotinoids. Journal of agricultural and food chemistry, 59(7), 2897-2908.

10. Elbert, A., Overbeck, H., Iwaya, K., \& Tsuboi, S. (1990). Imidacloprid, a novel systemic nitromethylene analogue insecticide for crop protection. In Brighton Crop Protection Conference, Pests and Diseases-1990. Vol. 1. (pp. 21-28). British Crop Protection Council.

11. Elbert, A., Becker, B., Hartwig, J., \& Erdelen, C. (1991). Imidacloprid-a new systemic insecticide. Pflanzenschutz-Nachrichten Bayer (Germany, FR).

12. Stoughton, S. J., Liber, K., Culp, J., \& Cessna, A. (2008). Acute and chronic toxicity of imidacloprid to the aquatic invertebrates Chironomus tentans and Hyalella azteca under constant-and pulseexposure conditions. Archives of Environmental Contamination and Toxicology, 54(4), 662-673.

13. Iwaya, K., \& Kagabu, S. (1998). Biological properties of the chloronicotinyl insecticide imidacloprid: high selectivity and safer use in practice. Reviews in Toxicology, 2(1), 121-132.

14. Cox, C. (2001). Insecticide Factsheet: imidacloprid, Northwest Coalition for Alternatives to Pesticides/NCAP, J. Pesticide Reform, 1: 21.

15. Ware, G. W., \& Whitacre, D. M. (2004). An introduction to insecticides. The pesticide book, 6 .

16. Tomlin, C.D.S. (2002). The e-Pesticide Manual. British Crop Protection Council, Hampshire, UK.

17. Felsot, A. S., Cone, W., Yu, J., \& Ruppert, J. R. (1998). Distribution of imidacloprid in soil following subsurface drip chemigation. Bulletin of environmental contamination and toxicology, 60(3), 363-370.

18. Nemeth-Konda, L., Füleky, G., Morovjan, G., \& Csokan, P. (2002). Sorption behaviour of acetochlor, atrazine, carbendazim, diazinon, imidacloprid and isoproturon on Hungarian agricultural soil. Chemosphere, 48(5), 545-552.

19. Rose, K.V.S., \& Joseph, A. (2019). A preliminary evaluation of leaching potential and persistence of biocides used in the paddy fields of kuttanad. Proceedings of AQUASEM '19. Cochin university of science and technology, India, 21-23 March.

20. Bai, D., Lummis, S. C., Leicht, W., Breer, H., \& Sattelle, D. B. (1991). Actions of imidacloprid and a related nitromethylene on cholinergic receptors of an identified insect motor neurone. Pesticide science, 33(2), 197-204.

21. Nauen, R., Tietjen, K., Wagner, K., \& Elbert, A. (1998). Efficacy of plant metabolites of imidacloprid against Myzus persicae and Aphis 
gossypii (Homoptera: Aphididae). Pesticide Science, 52(1), 53-57.

22. Alexander, A. C., Culp, J. M., Liber, K., \& Cessna, A. J. (2007). Effects of insecticide exposure on feeding inhibition in mayflies and oligochaetes. Environmental Toxicology and Chemistry: $A n$ International Journal, 26(8), 1726-1732.

23. Schmuck, R., Nauen, R., \& Ebbinghaus-Kintscher, U. (2003). Effects of imidacloprid and common plant metabolites of imidacloprid in the honeybee: toxicological and biochemical considerations. Bulletin of insectology, 56(1), 27-34.

24. Cox, L., Koskinen, W. C., Celis, R., Hermosin, M. C., Cornejo, J., \& Yen, P. Y. (1998). Sorption of imidacloprid on soil clay mineral and organic components. Soil Science Society of America Journal, 62(4), 911-915.

25. United States. Environmental Protection Agency. Office of Wastewater Management. (1995). A guide to the biosolids risk assessments for the EPA Part 503 rule. US Environmental Protection Agency, Office of Wastewater Management.

26. EFSA, G. (2008). Safety and nutritional assessment of GM plants and derived food and feed: the role of animal feeding trials. Food and chemical toxicology: an international journal published for the British Industrial Biological Research Association, 46, S2.

27. Amiard, J.C., Amiard-Triquet, C., Metayer, C., Marchand, J. \& Ferre, R. (1980). Study on the transfer of $\mathrm{Cd}, \mathrm{Pb}, \mathrm{Cu}$ and $\mathrm{Zn}$ in neritic and estuarine trophic chains. I. The inner estuary of the Loire (France) in the summer of 1978, Water Res. 14, 665-673.

28. Dutra, F. M., Rönnau, M., Sponchiado, D., Forneck, S. C., Freire, C. A., \& Ballester, E. L. C. (2017). Histological alterations in gills of Macrobrachium amazonicum juveniles exposed to ammonia and nitrite. Aquatic Toxicology, 187, 115123.

29. García, F., Gonzalez-Baró, M. R., Garda, H., Cunningham, M., \& Pollero, R. (2004). Fenitrothion-induced structural and functional perturbations in the yolk lipoproteins of the shrimp Macrobrachium borellii. Lipids, 39(4), 389-396.

30. Upadhyay, O. V., \& Shukla, G. S. (1986). Impact of phosphamidon on the carbohydrate metabolism of a freshwater prawn, Macrobrachium lamarrei. Environmental research, 41(2), 591-597.

31. Sarojini, R., Nagabhushanam, R., \& Mary, S. A. (1986). Effect of fenitrothion on reproduction of the freshwater prawn Macrobrachium lamerrii. Ecotoxicology and environmental safety, 11(3), 243-250.

32. Ali, A. A., Mannan, M. A., \& Parween, S. (2007). Effect of urea and malathion on the freshwater prawn, Macrobrachium lamarrei (HM Edwards). University Journal of Zoology, Rajshahi University, 26, 107-108.
33. Bhavan, P. S., \& Geraldine, P. (2000). Histopathology of the hepatopancreas and gills of the prawn Macrobrachium malcolmsonii exposed to endosulfan. Aquatic toxicology, 50(4), 331-339.

34. Bhavan, P. S., \& Geraldine, P. (2009). Manifestation of carbaryl toxicity on soluble protein and histopathology in the hepatopancreas and gills of the prawn, Macrobrachium malcolmsonii. J Environ Biol, 30(4), 533-8.

35. Selvakumar, S., Geraldine, P., Shanju, S., \& Jayakumar, T. (2005). Stressor-specific induction of heat shock protein 70 in the freshwater prawn Macrobrachium malcolmsonii (H. Milne Edwards) exposed to the pesticides endosulfan and carbaryl. Pesticide biochemistry and physiology, 82(2), 125132.

36. Shukla, G. S. (1984). Toxicity of the Herbicide 2.4D-Na to Two Species of Freshwater Prawn of the Genus Macrobrachium. Acta hydrochimica et hydrobiologica, 12(3), 285-289.

37. Yuan, Y. C., Chen, H. C., \& Yuan, Y. K. (2004). Sublethal effects of paraquat and malathion on the freshwater shrimp, Macrobrachium nipponense. Acta zoologica taiwanica, 14(2), 87-95.

38. Qiu, W., Chen, M., Song, Y., Zhou, J., \& Shan, Z. (2013). Acute toxicity of two pesticides to Macrobrachium nipponense. Journal of Ecology and Rural Environment, 29(5), 676-680.

39. Hong, Y., Yang, X., Huang, Y., Yan, G., \& Cheng, Y. (2018). Assessment of the oxidative and genotoxic effects of the glyphosate-based herbicide roundup on the freshwater shrimp, Macrobrachium nipponensis. Chemosphere, 210, 896-906.

40. Barbieri, E., Moreira, P., Luchini, L. A., Ruiz Hidalgo, K., \& Munoz, A. (2016). Assessment of acute toxicity of carbofuran in Macrobrachium olfersii (Wiegmann, 1836) at different temperature levels. Toxicology and Industrial Health, 32(1), 714.

41. Yeh, S. P., Sung, T. G., Chang, C. C., Cheng, W., \& Kuo, C. M. (2005). Effects of an organophosphorus insecticide, trichlorfon, on hematological parameters of the giant freshwater prawn, Macrobrachium rosenbergii (de Man). Aquaculture, 243(1-4), 383-392.

42. Chang, C. C., Lee, P. P., Liu, C. H., \& Cheng, W. (2006). Trichlorfon, an organophosphorus insecticide, depresses the immune responses and resistance to Lactococcus garvieae of the giant freshwater prawn Macrobrachium rosenbergii. Fish \& shellfish immunology, 20(4), 574-585.

43. Zhang, J., Zuo, Z., Chen, R., Chen, Y., \& Wang, C. (2008). Tributyltin exposure causes brain damage in Sebastiscus marmoratus. Chemosphere, 73(3), 337-343.

44. Chang, C. C., Rahmawaty, A., \& Chang, Z. W. (2013). Molecular and immunological responses of the giant freshwater prawn, Macrobrachium rosenbergii, to the organophosphorus insecticide, trichlorfon. Aquatic toxicology, 130, 18-26. 
45. Gaume, B., Dodet, N., Thomé, J. P., \& Lemoine, S. (2015). Expression of biotransformation and oxidative stress genes in the giant freshwater prawn Macrobrachium rosenbergii exposed to chlordecone. Environmental Science and Pollution Research, 22(11), 7991-8002.

46. Lafontaine, A., Hanikenne, M., Boulangé-Lecomte, C., Forget-Leray, J., Thomé, J. P., \& Gismondi, E. (2016). Vitellogenin and vitellogenin receptor gene expression and 20-hydroxyecdysone concentration in Macrobrachium rosenbergii exposed to chlordecone. Environmental Science and Pollution Research, 23(20), 20661-20671.

47. Blažič, M., Trebše, P., \& Drobne, D. (2005). Effect of imidacloprid on growth, feeding rate and activity of AChE and GST enzymes in the terrestrial isopods Porcellio scaber (Isopoda, Crustacea). Zbornik predavanj in referatov. 7. Slovensko posvetovanje o varstvu rastlin, 8.-10 marec, 2005, Zreče, Slovenija, 106-113.

48. Sánchez-Bayo, F., \& Goka, K. (2006). Influence of light in acute toxicity bioassays of imidacloprid and zinc pyrithione to zooplankton crustaceans. Aquatic toxicology, 78(3), 262-271.

49. Drobne, D., Blažič, M., Van Gestel, C. A., Lešer, V., Zidar, P., Jemec, A., \& Trebše, P. (2008). Toxicity of imidacloprid to the terrestrial isopod Porcellio scaber (Isopoda, Crustacea). Chemosphere, 71(7), 1326-1334.

50. Chen, X. D., Culbert, E., Hebert, V., \& Stark, J. D. (2010). Mixture effects of the nonylphenyl polyethoxylate, R-11 and the insecticide, imidacloprid on population growth rate and other parameters of the crustacean, Ceriodaphnia dubia. Ecotoxicology and Environmental Safety, 73(2), 132-137.

51. Lukančič, S., Žibrat, U., Mezek, T., Jerebic, A., Simčič, T., \& Brancelj, A. (2010). Effects of exposing two non-target crustacean species, Asellus aquaticus L., and Gammarus fossarum Koch., to atrazine and imidacloprid. Bulletin of environmental contamination and toxicology, 84(1), 85.

52. American Public Health Association, American Water Works Association, Water Pollution Control Federation, \& Water Environment Federation. (1915). Standard methods for the examination of water and wastewater (Vol. 2). American Public Health Association..

53. New, M. B., Valenti, W. C., Tidwell, J. H., D'Abramo, L. R., \& Kutty, M. N. (Eds.). (2009). Freshwater prawns: biology and farming. John Wiley \& Sons.

54. Peltier, W. H., \& Weber, C. I. (1985). Methods for measuring the acute toxicity of effluents to freshwater and marine organisms.

55. Armstrong, D. A., Stephenson, M. J., \& Knight, A. W. (1976). Acute toxicity of nitrite to larvae of the giant Malaysian prawn, Macrobrachium rosenbergii. Aquaculture, 9, 39-46.
56. Finney, D. J. (1952). Statistical method in biological assay. Statistical method in biological assay.

57. Boyd, C., \& Zimmermann, S. (2000). Grow-out systems-water quality and soil management. Freshwater prawn culture: the farming of Macrobrachium rosenbergii. Blackwell Science, Oxford, UK, 221-238.

58. CSI (Crop Science India). (2020). Crop and target pests of confidor, imidacloprid 200 SL.

59. Ruparelia, S.G., Verma, Y., Kashyap, S.K., \& Chatterjee B.B. (1983) Status reports on acute toxicity of pesticide in fishes in India. Proceedings of the seminar on the effect of Pesticides on aquatic fauna. Mhow, India, 18-22 June.

60. EPA (Environmental Protection Agency). (1985). Acute toxicity test for estuarine and marine organisms (shrimp 96-hour acute toxicity test). EPA-540/9-85-010.

61. American Public Health Association, American Water Works Association, Water Pollution Control Federation, \& Water Environment Federation. (1915). Standard methods for the examination of water and wastewater (Vol. 2). American Public Health Association.

62. Armstrong, D. A., Chippendale, D., Knight, A. W., $\&$ Colt, J. E. (1978). Interaction of ionized and unionized ammonia on short-term survival and growth of prawn larvae, Macrobrachium rosenbergh. The Biological Bulletin, 154(1), 1531.

63. Mallasen, M., \& Valenti, W. C. (2005). Larval development of the giant river prawn Macrobrachium rosenbergii at different ammonia concentrations and $\mathrm{pH}$ values. Journal of the World Aquaculture Society, 36(1), 32-41.

64. Figueroa-Lucero, G., \& HERNÁNDEZ-RUBIO, M. C. (2012). Acute toxicity of ammonia on Macrobrachium tenellum (Smith) larvae. Revista internacional de contaminación ambiental, 28(2), 145-150.

65. Dutra, F. M., Forneck, S. C., Brazão, C. C., Freire, C. A., \& Ballester, E. L. C. (2016). Acute toxicity of ammonia to various life stages of the Amazon river prawn, Macrobrachium amazonicum, Heller, 1862. Aquaculture, 453, 104-109.

66. Wajsbrot, N., Krom, M. D., Samocha, T. M., \& Gasith, A. (1990). Effect of dissolved oxygen and the molt stage on the acute toxicity of ammonia to juvenile green tiger prawn Penaeus semisulcatus. Environmental Toxicology and Chemistry: An International Journal, 9(4), 497-504.

67. Barbieri, E., de Oliveira, I. R., \& Serralheiro, P. C. (2002). The use of metabolism to evaluate the toxicity of dodecil benzen sodium sulfonate (LASC12) on the Mugil platanus (mullet) according to the temperature and salinity. Journal of Experimental Marine Biology and Ecology, 277(2), 109-127. 
68. Kagabu, S., \& Medej, S. (1995). Stability comparison of imidacloprid and related compounds under simulated sunlight, hydrolysis conditions, and to oxygen. Bioscience, biotechnology, and biochemistry, 59(6), 980-985.

69. Sohn, H. Y., Kwon, C. S., Kwon, G. S., Lee, J. B., \& Kim, E. (2004). Induction of oxidative stress by endosulfan and protective effect of lipid-soluble antioxidants against endosulfan-induced oxidative damage. Toxicology letters, 151(2), 357-365.

70. Tripathi, P. K., \& Singh, A. (2004). Carbaryl induced alterations in the reproduction and metabolism of freshwater snail Lymnaea acuminata. Pesticide biochemistry and physiology, 79(1), 1-9.

71. Malev, O., Klobučar, R. S., Fabbretti, E., \& Trebše, P. (2012). Comparative toxicity of imidacloprid and its transformation product 6-chloronicotinic acid to non-target aquatic organisms: Microalgae Desmodesmus subspicatus and amphipod Gammarus fossarum. Pesticide biochemistry and physiology, 104(3), 178-186.

72. Neury-Ormanni, J., Doose, C., Majdi, N., Vedrenne, J., Traunspurger, W., \& Morin, S. (2020). Selective grazing behaviour of chironomids on microalgae under pesticide pressure. Science of The Total Environment, 138673.

73. Azevedo-Pereira, H. M., Lemos, M. F., \& Soares, A. M. (2011). Behaviour and growth of Chironomus riparius Meigen (Diptera: Chironomidae) under imidacloprid pulse and constant exposure scenarios. Water, Air, \& Soil Pollution, 219(1-4), 215-224.

74. Chandran, N. N., Fojtova, D., Blahova, L., Rozmankova, E., \& Blaha, L. (2018). Acute and (sub) chronic toxicity of the neonicotinoid imidacloprid on Chironomus riparius. Chemosphere, 209, 568-577.

75. Cavallaro, M. C., Morrissey, C. A., Headley, J. V., Peru, K. M., \& Liber, K. (2017). Comparative chronic toxicity of imidacloprid, clothianidin, and thiamethoxam to Chironomus dilutus and estimation of toxic equivalency factors. Environmental toxicology and chemistry, 36(2), 372-382.

76. Raby, M., Zhao, X., Hao, C., Poirier, D. G., \& Sibley, P. K. (2018). Relative chronic sensitivity of neonicotinoid insecticides to Ceriodaphnia dubia and Daphnia magna. Ecotoxicology and environmental safety, 163, 238-244.

77. Bartlett, A. J., Hedges, A. M., Intini, K. D., Brown, L. R., Maisonneuve, F. J., Robinson, S. A., ... \& de Solla, S. R. (2019). Acute and chronic toxicity of neonicotinoid and butenolide insecticides to the freshwater amphipod, Hyalella azteca. Ecotoxicology and environmental safety, 175, 215223.

78. Xiao, X., Wu, Z. C., \& Chou, K. C. (2011). A multi-label classifier for predicting the subcellular localization of gram-negative bacterial proteins with both single and multiple sites. PloS one, 6(6), e20592.

79. Böttger, R., Feibicke, M., Schaller, J., \& Dudel, G. (2013). Effects of low-dosed imidacloprid pulses on the functional role of the caged amphipod Gammarus roeseli in stream mesocosms. Ecotoxicology and environmental safety, 93, 93100.

80. Sánchez-Bayo, F., \& Goka, K. (2006). Influence of light in acute toxicity bioassays of imidacloprid and zinc pyrithione to zooplankton crustaceans. Aquatic toxicology, 78(3), 262-271.

81. Agatz, A., Cole, T. A., Preuss, T. G., Zimmer, E., \& Brown, C. D. (2013). Feeding inhibition explains effects of imidacloprid on the growth, maturation, reproduction, and survival of Daphnia magna. Environmental science \& technology, 47(6), 2909-2917.

82. Schlussel, A., \& Leininger, E. (2019). Neonicotinoid insecticides and selective serotonin reuptake inhibitors interact antagonistically in Daphnia magna. Bios, 90(4), 245-256.

83. Schmitt, C. J., Stricker, C. A., \& Brumbaugh, W. G. (2011). Mercury bioaccumulation and biomagnification in Ozark stream ecosystems. Ecotoxicology and environmental safety, 74(8), 2215-2224.

84. Barbieri, E. (2008). Efeito dos Surfactantes DSS e LAS-C12 sobre o Camarão-rosa (Farfantepenaeus paulensi, Pérez-Farfante, 1967). J Braz Soc Ecotoxicol, 3(1), 35-40.

85. Dai, X., Xiong, Z., Xie, J., \& Ding, F. (2014). Acute toxicity of organochlorine insecticide endosulfan to the giant freshwater prawn Macrobrochium rosenbergii. Chinese Journal of Oceanology and Limnology, 32(1), 111-119.

86. Asih, A. Y. P., Irawan, B., \& Soegianto, A. (2013). Effect of copper on survival, osmoregulation, and gill structures of freshwater prawn (Macrobrachium rosenbergii, de Man) at different development stages. Marine and Freshwater Behaviour and Physiology, 46(2), 75-88.

87. Lin, H. P., Thuet, P., Trilles, J. P., MounetGuillaume, R., \& Charmantier, G. (1993). Effects of ammonia on survival and osmoregulation of various development stages of the shrimp Penaeus japonicus. Marine Biology, 117(4), 591-598.

88. Mallasen, M., \& Valenti, W. C. (2006). Effect of nitrite on larval development of giant river prawn Macrobrachium rosenbergii. Aquaculture, 261(4), 1292-1298.

89. Qi, S., Wang, C., Chen, X., Qin, Z., Li, X., \& Wang, C. (2013). Toxicity assessments with Daphnia magna of Guadipyr, a new neonicotinoid insecticide and studies of its effect on acetylcholinesterase (AChE), glutathione Stransferase (GST), catalase (CAT) and chitobiase activities. Ecotoxicology and environmental safety, 98, 339-344. 
90. Nicodemo, D., Maioli, M. A., Medeiros, H. C., Guelfi, M., Balieira, K. V., De Jong, D., \& Mingatto, F. E. (2014). Fipronil and imidacloprid reduce honeybee mitochondrial activity. Environmental toxicology and chemistry, 33(9), 2070-2075.

91. Resch, G., Held, A., Faber, T., Panzer, C., Toro, F., \& Haas, R. (2008). Potentials and prospects for renewable energies at global scale. Energy policy, 36(11), 4048-4056.

92. Brandt, A., Grikscheit, K., Siede, R., Grosse, R., Meixner, M. D., \& Büchler, R. (2017). Immunosuppression in honeybee queens by the neonicotinoids thiacloprid and clothianidin. Scientific reports, 7(1), 1-12.

93. BANAEI, M., MIR, V. A., Rafei, G. R., \& MAJAZI, A. B. (2008). Effect of sub-lethal diazinon concentrations on blood plasma biochemistry.

94. Fernandezcasalderrey, A., Ferrando, M. D., \& Andreumoliner, E. (1994). Effect of sublethal concentrations of pesticides on the feeding behavior of Daphnia magna. Ecotoxicology and environmental safety, 27(1), 82-89.

95. Qadir, S., Latif, A., Ali, M., \& Iqbal, F. (2014). Effects of imidacloprid on the hematological and serum biochemical profile of Labeo rohita. Pakistan Journal of Zoology, 46(4).

96. Islam, M. A., Hossen, M. S., Sumon, K. A., \& Rahman, M. M. (2019). Acute toxicity of imidacloprid on the developmental stages of common carp Cyprinus carpio. Toxicology and Environmental Health Sciences, 11(3), 244-251. 